\title{
Kościół prawosławny w drodze do Świętego i Wielkiego Soboru
}

Kościół prawosławny od wielu lat przygotowuje „Święty i Wielki Sobór"1. Przygotowania te mają swoją długą historię i naznaczone są wieloma problemami. Pomimo napotkanych trudności proces soborowych przygotowań wydaje się zmierzać ku końcowi i perspektywa zwołania soboru staje się coraz bliższa. Celem niniejszej

\footnotetext{
${ }^{1}$ Planowany przez prawosławie sobór nie jest nazywany „powszechnym” („ekumenicznym”), ale „Świętym i Wielkim” lub „wszechprawosławnym”, „panprawosławnym” czy „ogólnoprawosławnym” soborem. Wynika to - jak wyjaśniają teologowie prawosławni - z dwóch powodów. Po pierwsze, przyjęta nazwa odzwierciedla fakt, że będzie to sobór prawosławny, bez aktywnego i pełnoprawnego udziału innych chrześcijan. Po drugie, nazwa ta nawiązuje do soborów zwoływanych w pierwszych wiekach chrześcijaństwa; sobory te nie były a priori traktowane jako „powszechne”, ale taki charakter przyznawano im post factum. Niemniej jednak większość współczesnych teologów prawosławnych wyraża przekonanie, że prawosławie - analogicznie do postępowania Kościoła katolickiego po schizmie XI wieku - może dziś zwołać sobór powszechny, niezależnie od tego, jakim terminem zostanie on określony w momencie zwołania. Por. T. Kałużny, Nowy sobór ogólnoprawosławny. Natura, historia przygotowań, tematyka, Kraków 2008 [dalej = NSO], s. 131; Hilarion (Alfeyev), Le saint et grand concile de l'Église orthodoxe, „Irénikon” 84 (2011) nr 2-3, s. 205.
} 
refleksji będzie próba syntetycznego przedstawienia historii przygotowań soboru Kościoła prawosławnego.

Prezentowany temat zostanie rozwinięty w trzech częściach. Najpierw przedstawimy dwa zasadnicze etapy prawosławnej drogi do zwołania Świętego i Wielkiego Soboru: przygotowanie „dalsze” (1) i przygotowanie „bliższe” lub „bezpośrednie” (2). Pierwszy etap przygotowań skupia w sobie pojedyncze inicjatywy niektórych lokalnych Kościołów prawosławnych. Na tym etapie w świadomości prawosławnej obecna jest zaledwie ogólna idea soboru, która w kolejnych latach przygotowań przybiera coraz bardziej konkretny kształt. Natomiast inicjatywy podjęte na drugim etapie posiadają charakter zorganizowanego i oficjalnego procesu soborowych przygotowań, obejmującego cały świat prawosławny. W końcowej części zwrócimy uwagę na zasadnicze trudności powstałe na drodze soborowych przygotowań (3).

\section{Przygotowanie dalsze soboru}

U początku idei soboru wszechprawosławnego znalazła się encyklika Joakima III z 12 czerwca 1902 roku, w której patriarcha wzywał Kościoły prawosławne do szukania odpowiednich dróg urzeczywistnienia jedności wszechprawosławnej. W tym celu patriarcha Konstantynopola proponował Kościołom prawosławnym zwoływanie cyklicznych konferencji dla rozpatrywania aktualnych spraw kościelnych ${ }^{2}$. Zaproszenie patriarchy Joakima III nie spotkało się jednak z dostatecznym zrozumieniem ze strony innych Kościołów prawosławnych. Do sprawy zorganizowania wspólnego spotkania powrócono w następnych latach. W odpowiedzi na przedkładane propozycje, także ze strony innych Kościołów prawosławnych, zostały podjęte inicjatywy zmierzające do przygotowania

\footnotetext{
${ }^{2}$ Por. Lettre encyclique du Patriarche Joachim III et du Synode de l'Église de Constantinople a toutes les Églises orthodoxes (12 juin 1902), „Istina” 2 (1955),nr 1, s. 78-83.
} 
ogólnoprawosławnego spotkania3 ${ }^{3}$ Na szczególną uwagę zasługują: kongres Kościołów prawosławnych (Konstantynopol 1923); konferencja Kościołów prawosławnych (Vatopedi 1930); kongres teologów prawosławnych (Ateny 1936); konferencja zwierzchników Kościołów prawosławnych (Moskwa 1948).

Kongres Kościołów prawosławnych (Konstantynopol 1923)

Pierwsze konkretne kroki zmierzające do zwołania nowego soboru Kościoła prawosławnego podjęte zostały przez Patriarchat Ekumeniczny. W 1923 roku w Konstantynopolu, pod przewodnictwem patriarchy ekumenicznego Meletiosa IV, odbył się kongres prawosławny ${ }^{4}$. W czasie obrad kongresu przyjęto „poprawiony kalendarz juliański". Postanowiono także zwołać w roku 1925 - dla upamiętnienia 1600. rocznicy I Soboru Nicejskiego - sobór Kościołów prawosławnych w celu rozstrzygnięcia najważniejszych spraw kościelnych ${ }^{5}$. Pomimo podjętych w tym kierunku wysiłków zamierzenia tego nie udało się zrealizować.

Konferencja Kościołów prawosławnych (Watopedi 1930)

Ostatecznie w czerwcu 1930 roku w klasztorze Watopedi na górze Athos została zwołana Konferencja Kościołów prawosławnych

${ }^{3}$ Por. NSO, s. 140-143. Z propozycją zwołania spotkania ogólnoprawosławnego wystąpił w tym czasie m.in. metropolita Miron Cistea, późniejszy patriarcha Rumuńskiego Kościoła Prawosławnego. Por. V. Ionita, Auf dem Weg zum Heiligen und Großen Konzil der Orthodoxen Kirche, „Una Sancta” 70 (2015) nr 2, s. 83.

${ }^{4}$ W Kongresie uczestniczyli przedstawiciele Kościołów: Konstantynopola, Rumunii, Serbii, Grecji i Cypru. W spotkaniu wzięli także udział dwaj rosyjscy arcybiskupi: Anastasij (Gribanowski) z Kiszyniowa i Aleksandr (Niemolowski) z Ameryki Północnej. Natomiast nie przybyli na spotkanie przedstawiciele Patriarchatów: Antiocheńskiego, Aleksandryjskiego i Jerozolimskiego. Por. NSO, s. 144, przyp. 13.

${ }^{5}$ Por. Decisions of the Pan-Orthodox Congress [1923], [w:] P. Viscuso, A Quest for Reform of the Orthodox Church. The 1923 Pan-Orthodox Congress. An Analysis and Translation of its Acts and Decisions, Berkeley (California) 2006, s. 185-187. 
celem przygotowania wspólnego soboru ${ }^{6}$. W toku obrad Konferencji podjęto decyzję o zwołaniu spotkania przedsoborowego (presoboru) i uzgodniono listę 16 tematów, które zostaną przedstawione do dyskusji w czasie tego spotkania ${ }^{7}$.Zgodnie z postanowieniem Konferencji patriarcha ekumeniczny Fotios II przesłał wszystkim Kościołom autokefalicznym zaproszenie do wzięcia udziału w presoborze, którego zwołanie zostało zapowiedziane na niedzielę Pięćdziesiątnicy (19 czerwca) 1932 roku na górze Athos ${ }^{8}$.Zamierzenie to również tym razem nie znalazło swojej realizacji.

\section{Kongres teologów prawosławnych (Ateny 1936)}

Do sprawy zwołania soboru powrócono w czasie obrad I Kongresu teologów prawosławnych, który odbył się w Atenach w 1936 roku9. Stanowił on ważny moment w procesie dojrzewania idei zwołania soboru wszechprawosławnego. Kwestia soboru była przedmiotem kilku referatów wygłoszonych w czasie Kongresu. Uczestnicy spotkania nie zdołali jednak wypracować wspólnego stanowiska odnośnie do możliwości zwołania i charakteru soboru wszechprawosławnego. Uznali, że nie nadszedł jeszcze stosowny czas dla zwołania nowego soboru Kościoła prawosławnego ${ }^{10}$.

${ }^{6}$ W Konferencji nie wzięły udziału: Kościół Rosji, pozostający w izolacji spowodowanej przez reżim komunistyczny, oraz Kościoły Bułgarii i Albanii uważane wówczas za schizmatyckie. Por. NSO, s. 148, przyp. 25.

${ }^{7}$ Katalog tematów z Watopedi na górze Athos, zob. A. Kallis, Aufdem Weg zu einem Heiligen und Großen Konzil, Münster 2013, s. 129-131. Por. NSO, s. 148-149.

${ }^{8}$ Por. Brief des Ökumenischen Patriarchen Photios II. an die Vorsteher der autokephalen orthodoxen Kirchen (07.01.1931), [w:] A. Kallis, Auf dem Weg zu einem Heiligen und Großen Konzil, dz. cyt., s. 133-134.

${ }^{9}$ W spotkaniu wzięło udział kilkudziesięciu delegatów reprezentujących 8 prawosławnych wydziałów teologicznych. Por. NSO, s. 150, przyp. 30.

${ }^{10}$ Por. Le I Congrès de Théologie Orthodoxe [1936], Résolution (3 décembre 1936), [w:] Procè-verbaux du Premier Congrès de Théologie Orthodoxe à Athènes, 29 novembre-6 décembre 1936, Athènes 1939, s. 464-466; V. Ionita, Towards the Holy and Great Synod of the Orthodox Church. The Decisions of the Pan-Orthodox Meetings since 1923 until 2009, Basel 2014, s. 22-30. 
Konferencja zwierzchników Kościołów prawosławnych (Moskwa 1948)

W okresie po II wojnie światowej inicjatywę zwołania soboru wszechprawosławnego bądź też wspólnego spotkania przedsoborowego podjął Patriarchat Moskiewski. Od początku inicjatywa ta napotkała jednak trudności ze strony innych Kościołów prawosławnych, które dostrzegały w niej wpływ uwarunkowań politycznych oraz wyraz aspiracji Kościoła rosyjskiego do odegrania przewodniej roli w prawosławiu powszechnym. W tej sytuacji zorganizowana w Moskwie w 1948 roku Konferencja zwierzchników Kościołów prawosławnych nie przyniosła znaczących rezultatów w procesie przygotowań soboru wszechprawosławnego ${ }^{11}$.

Do idei soboru wszechprawosławnego powrócił na początku lat 50. XX wieku patriarcha ekumeniczny Athenagoras I. Dzięki jego inicjatywie i wysiłkom prawosławie wkroczyło na drogę bezpośrednich przygotowań soboru wszechprawosławnego.

\section{Przygotowanie bezpośrednie soboru}

Poszczególne fazy bezpośrednich przygotowań soborowych wyznaczają kolejne spotkania wszechprawosławne poświęcone tej problematyce. Na szczególną uwagę zasługują konferencje wszechprawosławne, posiedzenia międzyprawosławnej komisji przygotowawczej oraz wszechprawosławne konferencje przedsoborowe.

I Konferencja Wszechprawosławna (Rodos 1961)

Decyzja o podjęciu bezpośrednich przygotowań Soboru Wszechprawosławnego zapadła podczas I Konferencji Wszechprawosławnej, która odbyła się w dniach 24 września - 1 października 1961 roku na Rodos ${ }^{12}$. W toku prac Konferencji ustalono listę ponad stu tematów

\footnotetext{
${ }^{11}$ Por. NSO, s. 152-155; V. Ionita, Towards the Holy and Great Synod..., dz. cyt., s. 31-37.

${ }^{12}$ Por. V. Ionita, Auf dem Weg zum Heiligen und Großen Konzil der Orthodoxen Kirche, dz. cyt., s. 87-88. Było to pierwsze od blisko dwunastu stuleci tak reprezentatywne
} 
wymagających wspólnego rozpatrzenia oraz wstępną procedurę soborowych przygotowann ${ }^{13}$. Przyjęta procedura zakładała, że każdy $z$ autokefalicznych Kościołów prawosławnych przestudiuje wszystkie tematy zawarte w dość obszernym katalogu. Następnie zostanie zwołany presobór, który pozwoli na podsumowanie rezultatów badań i przygotowanie projektów dokumentów dla przyszłego Soboru Wszechprawosławnego ${ }^{14}$.

IV Konferencja Wszechprawosławna (Chambésy 1968)

Duże znaczenie dla procesu soborowych przygotowań miała IV Konferencja Wszechprawosławna, która odbyła się w dniach 8-15 czerwca 1968 roku w Centrum Patriarchatu Ekumenicznego w Chambésy koło Genewy (Szwajcaria). W celu koordynacji i przyśpieszenia prac przygotowawczych IV Konferencja powołała Międzyprawosławną Komisję Przygotowawczą do Świętego i Wielkiego Soboru oraz stały Sekretariat do spraw Przygotowania Świętego i Wielkiego Soboru z siedzibą w Centrum prawosławnym w Chambésy. Centrum to stało się odtąd stałym miejscem spotkań, mających na celu przygotowanie Soboru Wszechprawosławnego. $\mathrm{Na}$ czele Sekretariatu stanął przedstawiciel Patriarchatu Ekumenicznego, metropolita Damaskinos Papandreou (1936-2011) ${ }^{15}$.

spotkanie prawosławia. W Konferencji wzięli udział przedstawiciele 12 Kościołów prawosławnych: Patriarchatów Konstantynopola, Aleksandrii, Antiochii, Jerozolimy, Rosji, Serbii, Rumunii, Bułgarii oraz Kościołów Cypru, Grecji, Polski i Czechosłowacji. Por. NSO, s. 161-162.

${ }^{13}$ Lista tematów soborowych z Rodos, zob. La I Conférence Panorthodoxe de Rhodos [1961], Catalogue des thèmes du pro-synode projeté, ,Istina” 9 (1963) nr 1, s. 4953; tłum. polskie: NSO, dz.cyt., s. 391-396. Regulamin prac konferencji zob. Verfahrensund Arbeitsordung der I. Panorthodoxen Konferenz von Rhodos (25.09.1961), [w:] A. Kallis, Auf dem Weg zu einem Heiligen und Großen Konzil, dz. cyt., s. 246-250.

${ }^{14}$ Por. NSO, s. 163-164. Dwie kolejne konferencje na Rodos $(1963,1964)$ nie poruszyły bezpośrednio problematyki planowanego soboru lub presoboru.

${ }^{15}$ Metropolita Damaskinos stał na czele Sekretariatu do roku 2000, kiedy ciężko zachorował. Od 2003 roku funkcję sekretarza przejął metropolita Jeremiasz (Kaligouris). 
W toku prac Konferencji określono nową procedurę soborowych przygotowań. Zdecydowano o pominięciu w procesie przygotowań etapu „presoboru”, o którym mówiło się wcześniej. Postanowiono między innymi o zwoływaniu w przyszłości wszechprawosławnych konferencji przedsoborowych, na których byłyby rozpatrywane i zatwierdzane projekty dokumentów dla przyszłego soboru, przygotowane wcześniej przez międzyprawosławną komisję przygotowawczą na podstawie opracowań lokalnych Kościołów prawosławnych. Zgodnie z przyjętą procedurą z listy tematów ustalonej na Rodos w 1961 roku Konferencja w 1968 roku wybrała do opracowania w pierwszej fazie soborowych przygotowań sześć następujących tematów: 1) Źródła Bożego Objawienia; 2) Pełniejszy udział świeckich w liturgii i w całym życiu Kościoła; 3) Przystosowanie przepisów kościelnych dotyczących postu do wymagań współczesności; 4) Przeszkody małżeńskie; 5) Zagadnienie kalendarza; 6) Zasada ekonomii w Kościele prawosławnym ${ }^{16}$.

W dniach 16-28 lipca 1971 roku w Chambésy odbyło się pierwsze posiedzenie Międzyprawosławnej Komisji Przygotowawczej. Rozpatrzyła ona wstępne opracowania Kościołów lokalnych dotyczące sześciu tematów i przygotowała projekty dokumentów celem przedstawienia ich do zatwierdzenia przez I Wszechprawosławną Konferencję Przedsoborową ${ }^{17}$. Uznając listę tematów z 1961 roku za zbyt obszerną, Komisja wskazała na potrzebę jej gruntownej rewizji i znacznej redukcji oraz pewnej modyfikacji procedury soborowych przygotowań, przyjętej przez IV Konferencję w $1968 \mathrm{roku}^{18}$.

${ }^{16}$ Por. La IV Conférence Panorthodoxe [1968], Décisions [Chambésy, 15 juin 1968], [w:] Synodica VI, s. 125-128. Tłum. polskie: NSO, s. 473-483.

${ }^{17}$ Teksty projektów dokumentów wypracowanych przez Komisję w 1971 roku zob. Commission Interorthodoxe Préparatoire au Saint et Grand Concile de l'Église orthodoxe. Études des thèmes, „Contacts” 24 (1972) nr 80 (supplément).

${ }_{18}$ Por. Commission Interorthodoxe Préparatoire, Communiqué [Chambésy, 28 juillet 1971], „Episkepsis” 2 (1971) nr 36, s. 8-9. Tłum. polskie: NSO, s. 452-453. Dla członków Komisji stało się oczywiste, że opracowanie całego obszernego katalogu tematów z 1961 roku może stać się pracą na dziesięciolecia. Istotnie, przez dziesięć 
I Wszechprawosławna Konferencja Przedsoborowa (Chambésy 1976)

Pierwsza Wszechprawosławna Konferencja Przedsoborowa odbyła się w Chambésy w dniach 21-28 listopada 1976 roku. W rezultacie rewizji listy tematów - zgodnie z zaleceniem Komisji Przygotowawczej - Konferencja określiła nowy katalog dziesięciu podstawowych tematów dla przyszłego Soboru Wszechprawosławnego: 1) Diaspora prawosławna; 2) Autokefalia i sposób jej ogłaszania; 3) Autonomia i sposób jej ogłaszania; 4) Dyptychy; 5) Zagadnienie nowego kalendarza; 6) Przeszkody małżeńskie; 7) Przystosowanie przepisów kościelnych dotyczących postu; 8) Relacje Kościołów prawosławnych z pozostałym światem chrześcijańskim; 9) Prawosławie a ruch ekumeniczny; 10) Wkład lokalnych Kościołów prawosławnych w realizację chrześcijańskich ideałów pokoju, wolności, braterstwa i miłości między narodami oraz zniesienie dyskryminacji rasowej. Każdy z tych dziesięciu tematów został powierzony do wstępnego opracowania jednemu lub kilku Kościołom prawosławnym, które zostały zobowiązane do przesłania w ciągu sześciu miesięcy (maksymalnie w ciągu jednego roku) raportu do Sekretariatu do spraw Przygotowania Soboru. Materiały zebrane przez Sekretariat będą stanowić podstawę pracy Komisji Przygotowawczej oraz kolejnych konferencji przedsoborowych ${ }^{19}$.

lat, jakie minęły od I Konferencji na Rodos, żaden Kościół lokalny oprócz rosyjskiego nie zdołał uporać się z tym zadaniem. Stanowisko Patriarchatu Moskiewskiego w odniesieniu do wszystkich tematów katalogu z Rodos (1961) zob. Комиссия при Священном Синоде Русской Православной Церкви по разработке каталога тема Всеправославного Предсобора, Проекты резолютных документов, Москва 1968, maszynopis, 88 stron (w archiwum autora).

19 Por. Première Conférence Panorthodoxe Préconciliaire [1976], Décisions, [Chambésy, 28 novembre 1976], [w:] Synodica III, s. 113-117. Tłum. polskie: NSO, dz.cyt., s. 430-434. Na temat wyboru przez poszczególne Kościoły prawosławne konkretnych tematów soborowych do opracowania zob. NSO, s. 184-185. 


\section{Wszechprawosławna Konferencja Przedsoborowa} (Chambésy 1982)

Druga Wszechprawosławna Konferencja Przedsoborowa odbyła się w Chambésy w dniach 3-12 września 1982 roku. W porządku dnia Konferencji znalazły się trzy spośród dziesięciu tematów przyszłego soboru, a mianowicie: 1) Zagadnienie nowego kalendarza; 2) Przeszkody małżeńskie; 3) Przystosowanie przepisów kościelnych dotyczących postu ${ }^{20}$. Prace Konferencji prowadzono na posiedzeniach ogólnych oraz w powołanych dla przestudiowania każdego z tematów specjalnych komisjach. Konferencja przyjęła dwa teksty jako propozycję dla przyszłego soboru: Przeszkody matżeńskie ${ }^{21}$ i Zagadnienie kalendarza $a^{22}$. Tematyka postu została natomiast przekazana do ponownego rozpatrzenia na następnej konferencji przedsoborowej ${ }^{23}$.

W dniach 15-23 lutego 1986 roku w Chambésy zebrała się Międzyprawosławna Komisja Przygotowawcza. Komisja - zgodnie z decyzją Konferencji Przedsoborowej z 1982 roku - wypracowała wspólne stanowisko Kościołów prawosławnych w odniesieniu do

${ }^{20}$ Te trzy tematy porządku obrad II Konferencji Przedsoborowej zostały wybrane do rozpatrzenia i powierzone Kościołom do opracowania już przez IV Konferencję Wszechprawosławną (1968). W schematach dokumentów przedłożonych pod obrady obecnej Konferencji Przedsoborowej wzięto także pod uwagę wcześniejsze opracowania tematów oraz sugestie wniesione w tej materii przez odpowiednie Kościoły po I Konferencji Przedsoborowej (1976).

${ }^{21}$ Por. Deuxième Conférence Panorthodoxe Préconciliaire, Empêchements au mariage, [w:] Synodica VIII, s. 189-190. Tłum. polskie: NSO, s. 398-399.

${ }^{22}$ Por. Deuxième Conférence Panorthodoxe Préconciliaire, Question du calendrier, [w:] Synodica VIII, s. 190-191. Tłum. polskie: NSO, s. 400-401.

${ }^{23}$ Por. Deuxième Conférence Panorthodoxe Préconciliaire, Décisions proposées au Saint et Grand Concile, [w:] Synodica VIII, s. 189-192. Tłum. polskie: NSO, s. 438-439. Konferencja ustosunkowała się dodatkowo do zgłoszonej przez Kościół bułgarski sprawy „stanu mniszego biskupów”. Por. Deuxième Conférence Panorthodoxe Préconciliaire, Définition de normes futures en vue du sacre d'évêques choisis parmi les moines simplement rasophores et non uniquement parmi ceux qui ont reçu le grand schème, [w:] Synodica VIII, s. 190-191. 
następujących tematów: 1) Przystosowanie przepisów kościelnych dotyczących postu; 2) Relacje Kościołów prawosławnych z całym pozostałym chrześcijańskim; 3) Prawosławie a ruch ekumeniczny; 4) Wkład lokalnych Kościołów prawosławnych w realizację chrześcijańskich ideałów pokoju, wolności, braterstwa i miłości między narodami oraz zniesienie dyskryminacji rasowej. Komisja opracowała ponadto projekt regulaminu przygotowań soborowych ${ }^{24}$.

III Wszechprawosławna Konferencja Przedsoborowa (Chambésy 1986)

Trzecia Wszechprawosławna Konferencja Przedsoborowa odbyła się w Chambésy w dniach od 28 października do 6 listopada 1986 roku. Prace nad przewidzianymi pod obrady tematami odbywały się na sesjach ogólnych oraz w czterech komisjach. W toku obrad Konferencja przyjęła projekty czterech następujących dokumentów: Znaczenie postu i jego zachowanie dzisiaj ${ }^{25}$; Relacje Kościoła prawosławnego z pozostałym światem chrześcijańskim ${ }^{26}$; Kościół prawosławny a ruch ekumeniczny ${ }^{27}$; Wkład Kościoła prawosławnego w realizację pokoju, sprawiedliwości, wolności, braterstwa i miłości między narodami oraz zniesienie dyskryminacji rasowej i innej ${ }^{28}$. Konferencja zatwierdziła

${ }^{24}$ Por. Commission Interorthodoxe Préparatoire, Communiqué (Chambésy, 23 février 1986), „Episkepsis” 17 (1986) nr 351, s. 2-3. Tłum. polskie: NSO, s. 454-455. Teksty wypracowanych przez Komisję Przygotowawczą w 1986 r. wstępnych schematów dokumentów zob. „Episkepsis” 17 (1986) nr 354, s. 2-5.

${ }^{25}$ Por. Troisième Conférence Panorthodoxe Préconciliaire, Importance du jeûne et son observance aujourd'hui, „Episkepsis” 17 (1986) nr 369, s. 6-8. Tłum. polskie: NSO, s. 402-405.

${ }^{26}$ Por. Troisième Conférence Panorthodoxe Préconciliaire, Relations de l'Église orthodoxe avec l'ensemble du monde chrétien, „Episkepsis” 17 (1986) nr 369, s. 9-13. Tłum. polskie: NSO, s. 406-412.

${ }^{27}$ Por. Troisième Conférence Panorthodoxe Préconciliaire, Église orthodoxe et mouvement oecuménique, „Episkepsis” 17 (1986) nr 369, s. 14-17. Tłum. polskie: NSO, s. 413-417.

${ }^{28}$ Por. Troisième Conférence Panorthodoxe Préconciliaire, Contribution de l'Église orthodoxe à la réalisation de la paix, de la justice, de la liberté, de la fraternité et de l'amour 
również Regulamin Wszechprawosławnych Konferencji Przedsoborowych, określający funkcjonowanie Wszechprawosławnych Konferencji Przedsoborowych, Międzyprawosławnej Komisji Przygotowawczej oraz Sekretariatu do spraw Przygotowania Soboru ${ }^{29}$. Ponadto na III Konferencji Przedsoborowej postanowiono, iż pozostałe cztery zagadnienia (diaspora prawosławna, autokefalia, autonomia, dyptychy) zostaną rozpatrzone łącznie w czasie kolejnej, IV Konferencji Przedsoborowej ${ }^{30}$.

Prace związane z opracowaniem tych czterech tematów, zgodnie z przyjętą procedurą, zostały podjęte przez Sekretariat do spraw Przygotowania Soboru. Na podstawie opracowań, przesłanych przez lokalne Kościoły prawosławne, Sekretariat sporządził Raport o zbieżnościach i rozbieżnościach w czterech tematach IV Wszechprawosławnej Konferencji Przedsoborowej, opublikowany w 1987 roku $^{31}$.

Zadanie wypracowania wspólnego stanowiska w odniesieniu do pierwszego z czterech tematów - diaspory prawosławnej - podjęła Międzyprawosławna Komisja Przygotowawcza na posiedzeniu w dniach 10-17 listopada 1990 roku w Chambésy. Komisja nie zdołała jednak zakończyć prac nad projektem dokumentu na temat diaspory prawosławnej. Przyjęto jedynie projekt dokumentu w jego wstępnej redakcji, zawierający punkty, w których osiągnięto porozumienie ${ }^{32}$. Pracę nad tym tematem Komisja Przygotowawcza dokończyła na

entre les peuples, et à la suppression des discriminations raciales et autres, „Episkepsis” 17 (1986) nr 369, s. 18-26. Tłum. polskie: NSO, s. 418-429.

${ }^{29}$ Por. Troisième Conférence Panorthodoxe Préconciliaire, Règlement des Conférences Panorthodoxes Préconciliaires, „Episkepsis” 17 (1986) nr 369, s. 2-5. Tłum. polskie: NSO, s. 440-447.

${ }^{30}$ Por. Troisième Conférence Panorthodoxe Préconciliaire, Communiqué [Chambésy, 6 novembre 1986], „Episkepsis” 17 (1986) nr 366, s. 21-23.

${ }^{31}$ Por. Secrétariat pour la Préparation du Saint et Grand Concile de l'Église orthodoxе, Доклад о совпадениях и расхождениях по четырем темам повестки дня Всеправославного Предсоборного Совещания, Шамбези 1987 г., maszynopis, 16 stron (kopia w archiwum autora).

${ }^{32}$ Por. Commission Interorthodoxe Préparatoire, La diaspora orthodoxe (Chambésy, 17 novembre 1990), „Episkepsis” 22 (1991) nr 452, s. 21-22. Tłum. polskie: NSO, 
posiedzeniu w dniach 7-13 listopada 1993 roku, przyjmując nową redakcję projektu dokumentu na temat diaspory prawosławnej33. Komisja podjęła jednocześnie pracę nad projektem dokumentu na temat autokefalii w Kościele prawosławnym. Przyjęty przez Komisję w 1993 roku tekst na temat autokefalii nie uzyskał ostatecznego kształtu. Nie udało się wypracować wspólnego stanowiska dotyczącego podmiotu kompetentnego do ogłoszenia autokefalii ${ }^{34}$.

Dalsze prace nad tym zagadnieniem oraz pozostałymi tematami (autonomii i dyptychów) utrudniał poważny kryzys w relacjach międzyprawosławnych, spowodowany między innymi konfliktem między Patriarchatami Konstantynopola i Moskwy dotyczącym autonomii Kościoła w Estonii. Po bezskutecznej próbie powrotu do rozpatrzenia nierozstrzygniętych kwestii w sprawie autokefalii oraz pozostałych tematów podczas posiedzenia Komisji na przełomie lutego i marca 1999 roku, nastąpiło faktyczne zawieszenie procesu soborowych przygotowan' ${ }^{35}$.

Decyzja o wznowieniu procesu soborowych przygotowań zapadła podczas zgromadzenia (synaxis) zwierzchników autokefalicznych Kościołów prawosławnych, które odbyło się w dniach 10-12 październiku 2008 roku w Stambule ${ }^{36}$.

s. 456-457; Commission Interorthodoxe Préparatoire, Communiqué(Chambésy, 17 novembre 1990), „Episkepsis” 21 (1990) nr 450, s. 8-9.

33 Por. Commission Interorthodoxe Préparatoire, La diaspora orthodoxe [Chambésy, 13 novembre 1993], „Episkepsis” 24 (1993) nr 498, s. 22-23. Tłum. polskie: NSO, s. 460-461. Por. także Commission Interorthodoxe Préparatoire, Communiqué (Chambésy, 13 novembre 1993), „Episkepsis” 24 (1993) nr 498, s. 25.

${ }^{34}$ Por. Commission Interorthodoxe Préparatoire, L'autocéphalie et la manière de la proclamer [Chambésy, 13 novembre 1993], „Episkepsis” 24 (1993) nr 498, s. 23-24. Tłum. polskie: NSO, s. 462-463.

35 Por. Hilarion (Alfeyev), Le saint et grand concile..., dz. cyt., s. 223-224; NSO, s. 189, 198, 203-204; J. Oeldemann, Kommt das Panorthodoxe Konzil? Alte Konflikte und neue Konstellationen in der Orthodoxen Kirche, „Herder Korrespondenz” (2010) nr 11, s. 553557.

${ }^{36}$ Por. Le Message des Primats de Églises orthodoxes [2008], „Episkepsis” 39 (2008) nr 692, s. 26-30. 


\section{Wszechprawosławna Konferencja Przedsoborowa}

(Chambésy 2009)

W dniach 6-13 czerwca 2009 roku w Chambésy odbyła się IV Wszechprawosławna Konferencja Przedsoborowa. Uczestnicy Konferencji - nawiązując do materiału przygotowanego przez Międzyprawosławną Komisję Przygotowawczą w 1990 i 1993 roku przyjęli projekt dokumentu dla przyszłego soboru na temat Diaspory prawosławnej37. Zaakceptowano ponadto podział diaspory na określone regiony, w których zostaną utworzone zgromadzenia biskupów oraz Regulamin funkcjonowania zgromadzeń biskupów w diasporze prawosławnej3.

Prace nad nierozstrzygniętymi kwestiami w sprawie autokefalii oraz dwoma pozostałymi tematami dla przyszłego soboru (autonomią i dyptychami) kontynuowała Międzyprawosławna Komisja Przygotowawcza podczas dwóch kolejnych posiedzeń w dniach 9-17 grudniu 2009 oraz 22-26 lutego 2011 roku. Owocem obrad Komisji w 2009 roku był projekt dokumentu na temat autonomii. W toku prac Komisji nie udało się natomiast uzgodnić wspólnego stanowiska na temat autokefalii i dyptychów ${ }^{39}$.

Nowy impuls do dalszego przygotowania Świętego i Wielkiego Soboru dały postanowienia zgromadzenia (synaxis) zwierzchników autokefalicznych Kościołów prawosławnych, które odbyło się w dniach 6-9 marca 2014 roku w Fanarze (Stambule). Podczas tego

\footnotetext{
${ }^{37}$ Por. Quatrième Conférence Panorthodoxe Préconciliaire, La diaspora orthodoxe. Décisions, [w:] Synodica XII, s. 256-260.

${ }^{38}$ Por. Quatrième Conférence Panorthodoxe Préconciliaire, Règlement de fonctionnement des Assemblées épiscopales dans la diaspora orthodoxe, [w:] Synodica XII, s. 261265.

${ }^{39}$ Por. Commission Interorthodoxe Préparatoire, Communiqué (17 décembre 2009), http://www.ec-patr.org/docdisplay.php?lang=gr\&id=1141\&tla=fr (5.01.2016); Commission Interorthodoxe Préparatoire, Communiqué (26 février 2011), http:// orthodoxie.com/chambesy-fin-des-travaux-de-la-commission-preparatoire-interorthodoxe (5.01.2016); V. Ionita, Aufdem Weg zum Heiligen und Großen Konzil..., dz. cyt., s. 90 .
} 
spotkania między innymi zdecydowano o przyśpieszeniu procesu soborowych przygotowań. Utworzono specjalną Międzynarodową Komisję Przygotowawczą, która - obok pracy nad pozostałymi zagadnieniami katalogu tematów - została upoważniona do rewizji i uaktualnienia wcześniej przyjętych przez Konferencje Przedsoborowe projektów dokumentów. Postanowiono, że Sobór Wszechprawosławny zostanie zwołany przez patriarchę ekumenicznego w Konstantynopolu-Stambule w 2016 roku, o ile nie zaistnieją nieprzewidziane okoliczności. W końcu zalecono, aby w pierwszej połowie 2015 roku została zwołana V Wszechprawosławna Konferencja Przedsoborowa celem akceptacji pozostałych do opracowania projektów dokumentów, jak również uaktualnionych tekstów dla przyszłego soboru ${ }^{40}$.

Powołana w marcu 2014 roku specjalna Międzyprawosławna Komisja Przygotowawcza odbyła w Chambésy trzy posiedzenia. Pierwsze posiedzenie Komisji odbyło się w dniach 30 września 3 października 2014 r. W czasie spotkania dokonano rewizji dwóch tekstów przyjętych przez III Wszechprawosławną Konferencję Przedsoborową z 1986 roku, a mianowicie: Relacje Kościoła prawosławnego z pozostałym światem chrześcijańskim oraz Kościót prawosławny a ruch ekumeniczny ${ }^{41}$. Na drugim posiedzeniu Komisji w dniach 15-20 lutego 2015 roku dokonano weryfikacji części kolejnego projektu dokumentu, przyjętego również przez III Konferencję Przedsoborową w 1986 roku, a mianowicie: Wkład Kościoła prawosławnego w realizację pokoju, sprawiedliwości, wolności, braterstwa i miłości między narodami oraz zniesienie dyskryminacji rasowej $i$ innych. Tekst ten został sporządzony w czasach zimnej wojny i dlatego należało go uwolnić od wszelkich konotacji związanych z tym kontekstem. W nowej wersji

${ }^{40}$ Por. Message de la synaxe des primats des Églises orthodoxes, 9 mars 2014, „Istina” 59 (2014) nr 1, s. 73.

${ }^{41}$ Por. La session de la commission spéciale inter-orthodoxe pour la préparation du concile panorthodoxe s'est achevée, http://orthodoxie.com/la-session-de-la-commissionspeciale-inter-orthodoxe-pour-la-preparation-du-concile-panorthodoxe-sestachevee/ (21.12.2015). 
tekstu sformułowano szereg wytycznych dotyczących odniesienia Kościoła prawosławnego do różnych wyzwań dzisiejszego świata ${ }^{42}$. Trzecie posiedzenie specjalnej Komisji Przygotowawczej odbyło się w dniach 30 marca - 2 kwietnia 2015 roku. Podczas posiedzenia dokończono prace nad nową redakcją dokumentu Wkład Kościoła prawosławnego w realizację pokoju, sprawiedliwości, wolności, braterstwa i miłości między narodami oraz zniesienie dyskryminacji rasowej i innych. Planowano ponadto dokonać weryfikacji trzech innych tekstów: 1) Zagadnienie kalendarza; 2) Przeszkody małżeńskie; 3) Znaczenie postu i jego zachowanie dzisiaj. Ostatecznie z tych trzech projektów dokumentów sprawdzono tylko ostatni ${ }^{43}$.

\section{Wszechprawosławna Konferencja Przedsoborowa (Chambésy 2015)}

W dniach 10-17 października 2015 roku odbyła się w Chambésy V Wszechprawosławna Konferencja Przedsoborowa. Przyjęła ona przygotowany przez Międzyprawosławną Komisję Przygotowawczą w grudniu 2009 roku projekt dokumentu dla przyszłego soboru Autonomia i sposób jej ogłaszania ${ }^{44}$. Ponadto Konferencja zaakceptowała przygotowaną przez specjalną Komisję Przygotowawczą (2014, 2015) poprawioną wersję dokumentów: Znaczenie postu i jego zachowanie dzisiaj ${ }^{45}$ oraz Relacje Kościoła prawosławnego z pozostałym światem

${ }^{42}$ Por. La deuxième session de la commission inter-orthodoxe pour la préparation $\mathrm{du}$ saint et grand concile s'est achevée, http://www.orthodoxie.com/?s=\%C3\%A9tropo lite+J\%C3\%A9r\%C3\%A9mie+de+Suisse\&x=1189\&y=227 (21.12.2015).

${ }^{43}$ Por. Fin de la réunion de la commission interorthodoxe spéciale pour la préparation des documents ddu concile panorthodoxe [2.4.2015], https://mospat.ru/fr/2015/04/03/ news117382/ (21.12.2015).

${ }^{44}$ Por. Cinquième Conférence Panorthodoxe Préconciliaire, L'autonomie et la manière de la proclamer. Décision (Chambésy, 15 octobre 2015), https://mospat.ru/ fr/2016/01/28/news127358/(28.01.2016).

${ }^{45}$ Por. Cinquième Conférence Panorthodoxe Préconciliaire, L'importance du jeûne et son observation aujourd'hui. Décision (Chambésy, 16 octobre 2015), https://mospat. $\mathrm{ru} / \mathrm{fr} / 2016 / 01 / 28 /$ news127360/ (28.01.2016). 
chrześcijańskim ${ }^{46}$. Ten ostatni tekst w swej nowej redakcji powstał z połączenia dwóch zbliżonych treściowo tematów (nr 8 i 9 na liście z 1976 roku), dotyczących ekumenicznego zaangażowania Kościoła prawosławnego. W końcu Komisja zaakceptowała zmodyfikowany tekst Wkład Kościoła prawosławnego w realizację pokoju, sprawiedliwości, wolności, braterstwa i miłości między narodami oraz zniesienie dyskryminacji rasowej $i$ innych, który otrzymał nowy tytuł: Misja Kościoła prawosławnego we współczesnym świecie. Wkład Kościoła prawosławnego w realizację pokoju, sprawiedliwości, wolności, braterstwa i miłości między narodami oraz zniesienie dyskryminacji rasowej $i$ innych ${ }^{47}$. W odniesieniu do tego ostatniego projektu dokumentu, podczas V Konferencji Przedsoborowej w 2015 roku, w kilku kwestiach nie osiągnięto konsensusu. Tekst ten nie został podpisany przez delegacje rosyjskiego i gruzińskiego Kościoła prawosławnego ${ }^{48}$.

W rezultacie dokonanych przez Konferencję Przedsoborową w 2015 roku modyfikacji skróceniu uległa również lista tematów dla przyszłego soboru do dziewięciu następujących: 1) Diaspora prawosławna; 2) Autokefalia i sposób jej ogłaszania; 3) Autonomia i sposób jej ogłaszania; 4) Dyptychy; 5) Zagadnienie nowego kalendarza; 6) Przeszkody małżeńskie; 7) Znaczenie postu i jego zachowanie dzisiaj; 8) Relacje Kościoła prawosławnego z pozostałym światem chrześcijańskim; 9) Misja Kościoła prawosławnego we współczesnym świecie.

${ }^{46}$ Por. Cinquième Conférence Panorthodoxe Préconciliaire, Les relations de l'Église orthodoxe avec l'ensemble du monde chrétien. Décision (Chambésy, 15 octobre 2015), https://mospat.ru/fr/2016/01/28/news127362/ (28.01.2016).

${ }^{47}$ Por. Cinquième Conférence Panorthodoxe Préconciliaire, La mission de l'Église orthodoxe dans le monde contemporain. La contribution de l'Église orthodoxe à la realisation de la paix, de la justice, de la liberté, de la fraternité et de l'amour entre les peuples et à la suppression des discriminations raciales et autres. Décision (Chambésy, 16 octobre 2015), maszynopis, 12 stron (w archiwum autora).

${ }^{48}$ Por. Ve Conférence Panorthodoxe Préconciliaire. Communiqué (Chambésy, 10-17 octobre 2015), https://www.ec-patr.org/docdisplay.pdf?lang-gr\&id=2090\&tla-fr (21.12.2015). 
Przygotowaniem projektu regulaminu obrad Soboru Wszechprawosławnego zajęła się specjalna Międzyprawosławna Komisja Przygotowawcza na posiedzeniu w dniach 16-18 grudnia 2015 roku w Atenach. Podczas spotkania pojawiły się jednak liczne rozbieżności stanowisk i w rezultacie nie udało się urzeczywistnić tego zadania. Ponadto utrzymujące się napięcia w relacjach międzyprawosławnych i trudności przy opracowaniu pozostałych tematów soborowych sprawiły, że zapowiedziane na rok 2016 zwołanie Soboru Wszechprawosławnego ponownie stanęło pod znakiem zapytania ${ }^{49}$.

W tym kontekście duże znaczenie dla procesu soborowych przygotowań miało zgromadzenie (synaxis) zwierzchników autokefalicznych Kościołów prawosławnych, które odbyło się w dniach 21-28 stycznia 2016 roku w Chambésy. W czasie zgromadzenia postanowiono, że Święty i Wielki Sobór Kościoła prawosławnego odbędzie się w dniach 16-27 czerwca 2016 roku w Akademii Prawosławnej na Krecie. Uzupełniono i potwierdzono projekty dwóch dokumentów: Sakrament małżeństwa i przeszkody do jego zawarcia ${ }^{50}$ oraz Misja Kościoła prawosławnego we współczesnym świecie ${ }^{51}$. Ustalono, że sobór zajmie się rozpatrzeniem sześciu tematów, opracowanych i przyjętych w procesie przygotowań, a mianowicie: 1) Diaspora prawosławna; 2) Autonomia i sposób jej ogłaszania; 3) Sakrament małżeństwa i przeszkody do jego zawarcia; 4) Znaczenie postu i jego zachowanie dzisiaj; 5) Relacje Kościoła prawosławnego z pozostałym światem chrześcijańskim; 6) Misja Kościoła prawosławnego we współczesnym świecie. Uczestnicy zgromadzenia postanowili, że

${ }^{49}$ Por. Athenes, debut des travaux de la commission spéciale pour la préparation du concile panorthodoxe, https://mospat.ru/fr/2015/12/16/news126119/(21.12.2015).

${ }^{50}$ Por. Le sacrement du mariage et ses empêchements (Chambésy, 27 janvier 2016), https://mospat.ru/fr/2016/01/28/news127389/ (28.01.2016).

${ }^{51}$ Por. La mission de l'Église orthodoxe dans le monde contemporain. La contribution de l'Église orthodoxe à la realisation de la paix, de la justice, de la liberté, de la fraternité et de l'amour entre les peuples et à la suppression des discriminations raciales et autres (Chambésy, 27 janvier 2016), https://mospat.ru/fr/2016/01/28/news127353/ (28.01.2016). 
wszystkie zatwierdzone projekty dokumentów zostaną opublikowane. Ponadto w czasie zgromadzenia przedyskutowano i przyjęto Regulamin organizacji i funkcjonowania Świętego i Wielkiego Soboru Kościoła prawosławnego ${ }^{52}$.

W ten sposób przygotowanie soboru zdaje się zmierzać ku końcowi. Długi okres soborowych przygotowań rodzi jednocześnie uzasadnione pytanie o konkretne przeszkody lub trudności powstałe na drodze do urzeczywistnienia podjętego zamierzenia.

\section{Trudności na drodze soborowych przygotowań}

Trudności powstałe na drodze do zwołania Świętego i Wielkiego Soboru Kościoła prawosławnego koncentrują się zasadniczo wokół trzech następujących obszarów tematycznych: wątpliwości dotyczące potrzeby i możliwości zwołania soboru; zastrzeżenia do procesu soborowych przygotowań; problemy w relacjach międzyprawosławnych.

Wątpliwości dotyczące potrzeby i możliwości

zwołania soboru

Od samego początku soborowych przygotowań i w różnych jego fazach niektórzy przedstawiciele świata prawosławnego wyrażali pewne wątpliwości w odniesieniu do potrzeby i możliwości zwołania nowego soboru Kościoła prawosławnego. W związku z tym utrzymywali, że w ciągu pierwszych ośmiu wieków sobory powszechne lub generalne zwoływano głównie dla rozwiązania ważnych kwestii dogmatycznych. Obecnie zaś w Kościele prawosławnym nie ma

${ }^{52}$ Por. Règlement d'organisation et de fonctionnement du Saint et Grand Concile de l'Église orthodoxe (Chambésy, 27 janvier 2016), https://mospat.ru/fr/2016/01/28/ news127391/ (28.01.2016); Communiqué de la synaxe des primats des Églises orthodo xes à Chambésy, 21-28 janvier 2016, https://www.orthodoxie.com/communique-dela-synaxe-des-primats-des-eglises-orthodoxes-chambesy-21-28-janvier-2016/ (28.01.2016). Tekst Regulaminu nie został podpisany przez przedstawicieli Patriarchatu Antiochii. 
otwartych kwestii dogmatycznych, które wymagałyby soborowego rozwiązania. Natomiast aktualne problemy życia kościelnego mogą być rozwiązywane w czasie konferencji czy innych spotkań wszechprawosławnych. Skoro prawosławie żyło trzynaście wieków bez soborów wszechprawosławnych - zauważano - to przeżyje jeszcze drugie tyle ${ }^{53}$.

Większość prawosławnych nie podziela jednak tego rodzaju wątpliwości i jest przekonana o potrzebie zwołania Soboru Wszechprawosławnego. Teologowie prawosławni zauważają, że po upływie długiego czasu od zwołania VII soboru powszechnego w prawosławiu nagromadziło się wiele kwestii wymagających wspólnego soborowego rozwiązania. Do tych kwestii zalicza się między innymi rozbieżności w sprawie autokefalii i diaspory prawosławnej, które rodzą napięcia w relacjach międzyprawosławnych i utrudniają urzeczywistnienie prawosławnej misji we współczesnym świecie ${ }^{54}$. Prawosławni wydają się więc zasadniczo przychylni zwołaniu Soboru Wszechprawosławnego, pod warunkiem że zostanie on należycie przygotowany ${ }^{55}$.

${ }^{53}$ Por. J. Popovitch, Lettera sul Concilio [1971], „Oriente Cristiano” 17 (1977) nr 4, s. 106. Na ten temat zob. także Hilarion (Alfeyev), Le saint et grand concile..., dz.cyt., s. 241-242. Tego rodzaju wątpliwości doszły do głosu w sposób szczególny w pierwszym etapie soborowych przygotowań i wynikały w pewnym stopniu z braku jasnej koncepcji nowego soboru Kościoła prawosławnego. Istotnie, do IV Konferencji Wszechprawosławnej (1968) w procesie soborowych przygotowań mówiono zarówno o „soborze powszechnym”, jak i o „soborze wszechprawosławnym”. W świadomości prawosławnej pierwsze sobory powszechne stanowią zaś wydarzenie wyjątkowe i w pewnym sensie niepowtarzalne w życiu Kościoła. Nic więc dziwnego, że propozycja zwołania takiego soboru spotkała się z pewnymi zastrzeżeniami i wątpliwościami w świecie prawosławnym. Do takiej narracji („VIII sobór powszechny”) nawiązują też dzisiaj niektóre środowiska prawosławne, krytycznie nastawione do zwołania Soboru Wszechprawosławnego. Por. Hilarion (Alfeyev), Le saint et grand concile..., dz. cyt., s. 204, 242.

${ }^{54}$ Por. Hilarion (Alfeyev), Le saint et grand concile..., dz.cyt., s. 242. N. Lossky, Przygotowanie do Soboru panprawosławnego, „Novum” 12 (1978) nr 1, s. 19; P. Evdokimov, O. Clément, Vers le Concile. Appel à l'Église, „Contacts” 23 (1971) nr 73-74, s. 193-210.

${ }^{55}$ Por. NSO, s. 207-211. 
Zastrzeżenia do metody soborowych przygotowań

Na przygotowaniach do soboru zaciążyła także metoda soborowych przygotowań, która spotkała się z pewnymi zastrzeżeniami ze strony samych prawosławnych. Na trudności napotkało zwłaszcza ustalenie listy tematów dla przyszłego soboru, opracowanie niektórych tematów, jak również określenie samej procedury soborowych przygotowań i regulaminu obrad przyszłego soboru.

Pierwsze propozycje tematów wymagających wspólnego rozpatrzenia pojawiły sięjuż na początku XX wieku. Ta wstępna lista została uzupełniona o nowe propozycje, zgłaszane przez lokalne Kościoły prawosławne. Po przyjęciu na Rodos w 1961 roku szerokiej listy tematów odezwały się głosy krytyczne wskazujące na jej nieadekwatność w stosunku do aktualnych oczekiwań świata prawosławnego. W związku z tym Konferencja Przedsoborowa w 1976 roku radykalnie skróciła listę z Rodos (1961) do dziesięciu tematów soborowych. Również ta nowa lista tematów spotkała się z pewnymi zastrzeżeniami, między innymi z powodu pominięcia niektórych zagadnień, zawartych na liście z Rodos. Konferencja Przedsoborowa w 2015 roku zmodyfikowała tę listę do dziewięciu tematów. Na zgromadzeniu zwierzchników Kościołów prawosławnych w styczniu 2016 roku zapadła zaś decyzja o przedłożeniu pod obrady przyszłego soboru jedynie sześciu tematów ${ }^{56}$.

Trudności pojawiły się również w toku opracowania niektórych tematów. Duże rozbieżności stanowisk doszły do głosu między innymi w toku prac nad projektem dokumentu na temat ekonomii eklezjalnej (w katalogu z 1961 roku). Ostatecznie, zgodnie z decyzją Konferencji z 1976 roku, temat ten został wyłączony z porządku obrad przyszłego soboru. Mając na uwadze aktualny katalog tematów, bardzo trudnym przedsięwzięciem okazuje się wypracowanie wspólnego stanowiska Kościołów prawosławnych, zwłaszcza w odniesieniu do czterech zagadnień, a mianowicie diaspory prawosławnej,

${ }^{56}$ Por. NSO, s. 213-218, 259-283; Communiqué de la synaxe des primats des Églises orthodoxes à Chambésy, 21-28 janvier 2016, cyt. 
autokefalii, autonomii i dyptychów. Nie bez trudności przebiegał także proces opracowania pozostałych tematów dla przyszłego soboru ${ }^{57}$.

Z zastrzeżeniami spotkała się procedura przygotowania przyszłego soboru, określana i precyzowana w różnych fazach procesu soborowych przygotowań. Ustalona procedura zakłada między innymi, że projekty dokumentów dla przyszłego soboru przyjmowane są przez Konferencje Przedsoborowe jednomyślnie. Jedynie uchwały w sprawach proceduralnych podejmowane są większością dwóch trzecich głosów ${ }^{58}$. W ostatnich latach jednak niektóre Kościoły prawosławne, zaniepokojone trudnościami związanymi z wypracowaniem wspólnego stanowiska w wielu kwestiach i wydłużającym się procesem soborowych przygotowań, zgłosiły postulat zrezygnowania z jednomyślności i wprowadzenia zasady większości przy podejmowaniu uchwał w sprawie tekstów dla przyszłego soboru. Propozycja ta spotkała się z ostrą reakcją innych Kościołów prawosławnych, które wystąpiły w obronie zasady konsensusu ${ }^{59}$. Ostatecznie Kościoły prawosławne opowiedziały się za utrzymaniem zasady konsensusu, zarówno w procesie przygotowań, jak i na samym Soborze Wszechprawosławnym ${ }^{60}$.

Odnosząc się w sposób całościowy do procesu soborowych przygotowań, teologowie prawosławni przyznają, że do tej pory idea zwołania Świętego i Wielkiego Soboru wzbudziła stosunkowo mało zainteresowania zarówno wśród wiernych świeckich, jak i duchownych.

${ }^{57}$ Por. NSO, s. 280-281, 352-380. Przyjęty przez V Konferencję Przedsoborową zmodyfikowany projekt dokumentu na temat Misji Kościoła prawosławnego we wspótczesnym świecie - jak zauważono wcześniej - nie został podpisany przez Kościoły Rosji i Gruzji. Tekst ten został ostatecznie zaakceptowany dopiero na zgromadzeniu zwierzchników autokefalicznych Kościołów prawosławnych w styczniu 2016 roku.

${ }^{58}$ Por. Troisième Conférence Panorthodoxe Préconciliaire, Règlement des Conférences Panorthodoxes Préconciliaires, dz. cyt., art. 16.

${ }^{59} \mathrm{~W}$ obronie zasady jednomyślnego podejmowania decyzji wystąpił między innymi Patriarchat Moskiewski. Por. Hilarion (Alfeyev), Le saint et grand concile..., dz.cyt., s. 236-237.

${ }^{60}$ Por. Règlement d'organisation et de fonctionnement du Saint et Grand Concile de l'Église orthodoxe (Chambésy, 27 janvier 2016), dz.cyt., art. 11. 
Jest to efektem ograniczenia procesu przygotowań do wąskiej grupy ekspertów, braku dostatecznej informacji wiernych świeckich na ten temat, jak również braku powszechnego dostępu do projektów dokumentów dla przyszłego soboru. Taka sytuacja braku jawności i otwartości prowadzonych prac przygotowawczych wywołuje niejednokrotnie podejrzliwość, uniemożliwia dyskusję, właściwą ocenę i recepcję idei Świętego i Wielkiego Soboru. W związku z tym w różnych fazach soborowych przygotowań pojawiały się głosy o rzetelną informację o soborze, która przyczyni się do obudzenia prawdziwej świadomości soborowej w Kościele prawosławnym. Wydaje się jednak, że postulaty te nie zostały w sposób dostateczny uwzględnione w dotychczasowym procesie soborowych przygotowań, skoro na tego rodzaju niedomagania metodologii tych przygotowań ponownie wskazał moskiewski patriarcha Cyryl (Gundiajew) podczas zgromadzenia (synaxis) zwierzchników autokefalicznych Kościołów prawosławnych w styczniu 2016 roku $^{61}$. W związku z tym uczestnicy wspomnianego zgromadzenia w styczniu 2016 roku postanowili, że wszystkie zatwierdzone projekty dokumentów dla przyszłego soboru zostaną opublikowane.

Problemy w relacjach międzyprawosławnych

W końcu na proces soborowych przygotowań mają duży wpływ problemy w relacjach międzyprawosławnych, wynikające głównie z różnicy zdań między Kościołami prawosławnymi co do autokefalii i autonomii niektórych Kościołów oraz organizacji diaspory prawosławnej. Trudności te mają zróżnicowany charakter i obejmują trzy zasadnicze obszary: relacje między prawosławiem „greckim” i „słowiańskim”, zwłaszcza zaś między Patriarchatem Konstantynopolitańskim i Patriarchatem Moskiewskim, wewnętrzne

${ }^{61}$ Por. O. Clément, Tous, préparons ensemble le Concile, [w:] Synodica I, s. 122-123; La formation du peuple chrétien pour le futur Grand Concile de l'Église orthodoxe, „Episkepsis” 2 (1971) nr 23, s. 5; NSO, s. 218-220; Allocution du Patriarche Cyrille de Moscou à la synaxe des primats des Églises orthodoxes [22 janvier 2016], https://mospat.ru/fr/2016/01/22/ news127085/ (28.01.2016). 
stosunki między Kościołami „greckimi” oraz relacje w łonie Kościołów „słowiańskich”62.

Szczególnie dotkliwie daje się we znaki konflikt między Konstantynopolem i Moskwą, mający swe źródło przede wszystkim w różnicach co do koncepcji prymatu wewnątrzprawosławnego. Konflikt ten ujawnił się między innymi w 1970 roku w kontekście przyznania przez Patriarchat Moskiewski statusu autokefalii Metropolii Prawosławnej w Ameryce. Akt ten nie został zaakceptowany przez niektóre Kościoły prawosławne, w tym przez Patriarchat Ekumeniczny. W latach 90. ubiegłego wieku doszło do ostrego sporu między Konstantynopolem i Moskwą, kiedy Patriarchat Konstantynopola - na prośbę wielu prawosławnych Estończyków przywrócił Kościołowi prawosławnemu w Estonii status autonomii, co z kolei wywołało oburzenie Patriarchatu Moskiewskiego, który odebrał ten gest jako zamach na swoją suwerenność. Nic więc dziwnego, że obecność przedstawicieli Apostolskiego Kościoła Estonii (jurysdykcji Patriarchatu Konstantynopola) na spotkaniach międzyprawosławnych, w tym dotyczących soborowych przygotowań, spotykała się z ostrym protestem Patriarchatu Moskiewskiego i była jedną z przyczyn zawieszenia procesu soborowych przygotowań w latach 90. XX wieku. Przygotowania te zostały wznowione po osiągnięciu na spotkaniu zwierzchników Kościołów prawosławnych w październiku 2008 roku porozumienia, zgodnie z którym w wszechprawosławnych spotkaniach przedsoborowych uczestniczą tylko przedstawiciele Kościołów autokefalicznych ${ }^{63}$. Napięcia między dwoma patriarchatami związane są również z aktualną sytuacją na Ukrainie, gdzie działają wspólnoty prawosławne podległe Moskwie oraz inne, niezależne od niej, które podlegają lub chcą

\footnotetext{
${ }^{62}$ Więcej na ten temat zob. T. Kałużny, Problem eklezjalnej jedności prawosławia $w$ dzisiejszej Europie, „Studia Oecumenica” 8 (2008), s. 77-93.

${ }^{63}$ Por. Hilarion (Alfeyev), Le saint et grand concile..., dz.cyt., s. 223-224; Jerzy (Pańkowski), Aktualny stan przygotowań do Soboru Panprawosławnego, „Elpis” 12 (2010) nr 21-22, s. 170-171.
} 
podlegać Konstantynopolowi ${ }^{64}$. Z kolei w Kościele Prawosławnym Czech i Słowacji w kontekście wyboru w 2014 roku metropolity Rościsława na nowego zwierzchnika tegoż Kościoła powstał spór między przedstawicielami „nurtu promoskiewskiego” a zwolennikami zbliżenia z Patriarchatem Konstantynopola, który przez pewien czas kwestionował kanoniczność tego wyboru. Spór ten został rozwiązany dopiero w styczniu 2016 roku, kiedy metropolita Rościsław został uznany przez Konstantynopol za kanonicznego zwierzchnika Kościoła Prawosławnego Czech i Słowacji ${ }^{65}$. Nie bez wpływu na proces soborowych przygotowań pozostaje również zaistniały w 2013 roku spór między patriarchatami w Jerozolimie i Antiochii w związku z mianowaniem przez Jerozolimę własnego biskupa dla Kataru na Półwyspie Arabskim i utworzeniu tam samodzielnej diecezji, podczas gdy Antiochia uważa, że ten kraj pozostaje w jej jurysdykcji ${ }^{66}$.

Podsumowując, należy stwierdzić, że przygotowania zmierzające do zwołania Soboru Wszechprawosławnego mają już swoją długą historię. Można w niej wyróżnić dwa zasadnicze etapy: przygotowanie dalsze, czyli pojedyncze inicjatywy niektórych lokalnych Kościołów prawosławnych, które sięgają początku XX wieku, oraz przygotowanie bezpośrednie, zapoczątkowane przez Wszechprawosławną Konferencję na Rodos w 1961 roku. Konkretne kroki tej oficjalnej drogi bezpośrednich przygotowań soboru wyznaczają kolejne spotkania Międzyprawosławnej Komisji Przygotowawczej (1971, 1986, 1990, 1993, 1999, 2011), a następnie specjalnej Międzyprawosławnej Komisji Przygotowawczej (2014, trzy spotkania w 2015) oraz Wszechprawosławnych Konferencji Przedsoborowych (1976, 1982, 1986, 2009, 2015). Działania te wspomagane są stosownymi decyzjami

\footnotetext{
${ }^{64}$ Por. NSO, s. 80-81.

${ }^{65}$ Pог. Константинополь признал митрополита Ростислава предстоятелем Церкви Чешских земль, http://regions.ru/news /2569691/ (15.01.2016).

${ }^{66}$ Por. Przygotowania do Soboru Wszechprawosławnego, http://ekai.pl/wydarze nia/ekumeniczne/x95268/przygotowania-do-soboru-wszechprawosławnego/ (8.01.2016).
} 
zgromadzeń zwierzchników autokefalicznych Kościołów prawosławnych i koordynowane przez stały Sekretariat do spraw Przygotowania Świętego i Wielkiego Soboru.

Proces soborowych przygotowań okazał się złożony i naznaczony wieloma trudnościami i problemami. Równocześnie ten długi i trudny okres przygotowań soboru ma również pozytywne strony. Odkładanie terminu zwołania soboru pozwoliło niewątpliwie lokalnym Kościołom prawosławnym na umocnienie wzajemnych relacji oraz wspólne i dogłębne przestudiowanie aktualnych zagadnień. Pozwoliło także na przemyślenie na nowo samej koncepcji soboru. Można zatem powiedzieć, że ten długi proces soborowych przygotowań jest dla prawosławia równie ważny, jak sam sobór. Jest on częścią soborowego życia Kościoła prawosławnego. Wszystko to pozwala mieć nadzieję, że wysiłki podjęte na drodze soborowych przygotowań zaowocują w całej pełni na bliskim już Soborze Wszechprawosławnym.

\section{Bibliografia}

\section{Dokumenty}

Brief des Ökumenischen Patriarchen Photios II. an die Vorsteher der autokephalen orthodoxen Kirchen (07.01.1931), [w:] A. Kallis, Auf dem Weg zu einem Heiligen und Großen Konzil, Münster 2013, s. 133-134.

Ve Conférence Panorthodoxe Préconciliaire. Communiqué (Chambésy, 10-17 octobre 2015), https://www.ec-patr.org/docdisplay.pdf?lang-gr\&id=2090\&tla-fr (21.12.2015).

Cinquième Conférence Panorthodoxe Préconciliaire, La mission de l'Église orthodoxe dans le monde contemporain. La contribution de l'Église orthodoxe à la realisation de la paix, de la justice, de la liberté, de la fraternité et de l'amour entre les peuples et à la suppression des discriminations raciales et autres. Décision (Chambésy, 16 octobre 2015), maszynopis, 12 stron (w archiwum autora).

Cinquième Conférence Panorthodoxe Préconciliaire, L'autonomie et la manière de la proclamer. Décision (Chambésy, 15 octobre 2015), https://mospat.ru/ fr/2016/01/28/news127358/ (28.01.2016). 
Cinquième Conférence Panorthodoxe Préconciliaire, Les relations de l'Église orthodoxe avec l'ensemble du monde chrétien. Décision (Chambésy, 15 octobre 2015), https://mospat.ru/fr/2016/01/28/news127362/ (28.01.2016).

Cinquième Conférence Panorthodoxe Préconciliaire, L'importance dujeûne et son observation aujourd'hui. Décision (Chambésy, 16 octobre 2015), https:// mospat.ru/fr/2016/01/28/news127360/ (28.01.2016).

Cinquième Conférence Panorthodoxe Préconciliaire, Règlement d'organisation et de fonctionnement du Saint et Grand Concile de l'Église orthodoxe (Chambésy, 27 janvier 2016), https://mospat.ru/fr/2016/01/28/news127391/(28.01.2016).

Commission Interorthodoxe Préparatoire au Saint et Grand Concile de l'Église orthodoxe. Études des thèmes, „Contacts” 24 (1972) nr 80 (supplément).

Commission Interorthodoxe Préparatoire, Communiqué [Chambésy, 28 juillet 1971], „Episkepsis” 2 (1971) nr 36, s. 8-9; tłum. polskie: NSO, s. 452-453.

Commission Interorthodoxe Préparatoire, Communiqué (Chambésy, 23 février 1986), „Episkepsis” 17 (1986) nr 351, s. 2-3; tłum. polskie: NSO, s. 454-455.

Commission Interorthodoxe Préparatoire, Communiqué (Chambésy, 17 novembre 1990), „Episkepsis” 21 (1990) nr 450, s. 8-9.

Commission Interorthodoxe Préparatoire, Communiqué (Chambésy, 13 novembre 1993), „Episkepsis” 24 (1993) nr 498, s. 25.

Commission Interorthodoxe Préparatoire, Communiqué (17 décembre 2009), http://www.ec-patr.org/docdisplay.php?lang=gr\&id=1141\&tla=fr (5.01.2016).

Commission Interorthodoxe Préparatoire, Communiqué (26 février 2011), http://orthodoxie.com/chambesy-fin-des-travaux-de-la-commissionpreparatoire-inter-orthodoxe (5.01.2016).

Commission Interorthodoxe Préparatoire, La diaspora orthodoxe (Chambésy, 17 novembre 1990), „Episkepsis” 22 (1991) nr 452, s. 21-22; tłum. polskie: NSO, s. $456-457$.

Commission Interorthodoxe Préparatoire, La diaspora orthodoxe [Chambésy, 13 novembre 1993], „Episkepsis” 24 (1993) nr 498, s. 22-23; tłum. polskie: NSO, s. $460-461$.

Commission Interorthodoxe Préparatoire, L'autocéphalie et la manière de la proclamer [Chambésy, 13 novembre 1993], „Episkepsis” 24 (1993) nr 498, s. 23-24; tłum. polskie: NSO, s. 462-463.

Communiqué de la synaxe des primats des Églises orthodoxes à Chambésy, 21-28 janvier 2016, https://www.orthodoxie.com/communique-de-la-synaxe-desprimats-des-eglises-orthodoxes-chambesy-21-28-janvier-2016/ (28.01.2016). 
Decisions of the Pan-Orthodox Congress [1923], [w:] P. Viscuso, A Quest for Reform of the Orthodox Church. The 1923 Pan-Orthodox Congress. An Analysis and Translation of its Acts and Decisions, Berkeley (California) 2006, s. 185-187.

Deuxième Conférence Panorthodoxe Préconciliaire. [Procès-verbaux et textes], Chambésy, 3-12 septembre 1982, [Synodica VIII], Chambésy (Genève) 1994 [=Synodica VIII].

Deuxième Conférence Panorthodoxe Préconciliaire, Décisions proposées au Saint et Grand Concile, [w:] Synodica VIII, s. 189-192; tłum. polskie: NSO, s. 438439.

Deuxième Conférence Panorthodoxe Préconciliaire, Définition de normes futures en vue du sacre d'évêques choisis parmi les moines simplement rasophores et non uniquement parmi ceux qui ont reçu le grand schème, [w:] Synodica VIII, s. 190-191.

Deuxième Conférence Panorthodoxe Préconciliaire, Empêchements au mariage, [w:] Synodica VIII, s. 189-190; tłum. polskie: NSO, s. 398-399.

Deuxième Conférence Panorthodoxe Préconciliaire, Question du calendrier, [w:] Synodica VIII, s. 190-191; tłum. polskie: NSO, s. 400-401.

Комиссия при Священном Синоде Русской Православной Церкви по разработке каталога тема Всеправославного Предсобора, Проекты резолютных документов, Москва 1968, maszynopis, 88 stron (w archiwum autora).

La mission de l'Église orthodoxe dans le monde contemporain. La contribution de l'Église orthodoxe à la realisation de la paix, de la justice, de la liberté, de la fraternité et de l'amour entre les peuples et à la suppression des discriminations raciales et autres (Chambésy, 27 janvier 2016), https://mospat.ru/fr/2016/01/28/news127353/ (28.01.2016).

La I Conférence Panorthodoxe de Rhodos [1961], [w:] Catalogue des thèmes du pro-synode projeté, „Istina” 9 (1963) nr 1, s. 49-53; tłum. polskie: NSO, s. 391-396.

La IV Conférence Panorthodoxe [1968], Décisions [Chambésy, 15 juin 1968], [w:] Synodica VI, s. 125-135; tłum. polskie: NSO, s. 473-483.

Le Message des Primats de Églises orthodoxes [2008], „Episkepsis” 39 (2008) nr 692, s. 26-30.

Le I Congrès de Théologie Orthodoxe [1936], Résolution (3 décembre 1936), [w:] Procè-verbaux du Premier Congrès de Théologie Orthodoxe à Athènes, 29 novembre-6 décembre 1936, Athènes 1939, s. 464-466.

Lettre encyclique du Patriarche Joachim III et du Synode de l'Église de Constantinople a toutes les Églises orthodoxes (12 juin 1902), „Istina” 2 (1955) nr 1, s. 78-83.

Kallis A., Auf dem Weg zu einem Heiligen und Großen Konzil, Münster 2013. 
Message de la synaxe des primats des Églises orthodoxes, 9 mars 2014, „Istina” 59 (2014) nr 1, s. 71-73.

Première Conférence Panorthodoxe Préconciliare. [Procès-verbaux et textes], Chambésy, 21-28 novembre 1976, [Synodica III], Chambésy (Genève) 1979 [=Synodica III].

Première Conférence Panorthodoxe Préconciliaire [1976], Décisions, [Chambésy, 28 novembre 1976], [w:] Synodica III, s. 113-117; tłum. polskie: NSO, s. 430-434.

Quatrième Conférence Panorthodoxe. Procès-verbaux et textes [w j.gr. i fr. - wybrane teksty], (Chambésy-Geneve, 28 juin - 3 juillet 1977), [Synodica VI], Chambésy (Genève) 1982 [=Synodica VI].

IVConférence Panorthodoxe Préconciliaire. Procès-verbaux-documents, (Chambésy, 6-13 juin 2009), [Synodica XII], Chambésy (Genève) 2015 [=Synodica XII].

Quatrième Conférence Panorthodoxe Préconciliaire, La diaspora orthodoxe. Décisions, [w:] Synodica XII, s. 256-260.

Quatrième Conférence Panorthodoxe Préconciliaire, Règlement de fonctionnement des Assemblées épiscopales dans la diaspora orthodoxe, [w:] Synodica XII, s. 261-265.

Règlement d'organisation et de fonctionnement du Saint et Grand Concile de l'Église orthodoxe (Chambésy, 27 janvier 2016), https://mospat.ru/fr/2016/01/28/ news127391/ (28.01.2016).

Secrétariat pour la Préparation du Saint et Grand Concile de l'Église orthodoхе, Доклад о совпадениях и расхождениях по четырем темам повестки дня Всеправославного Предсоборного Совещзания, Шамбези 1987 г., maszynopis, 16 stron (kopia w archiwum autora).

Synodica I [Publication du Secretariat pour la Préparation du Saint et Grand Concile de l'Église orthodoxe], Chambésy (Genève) 1976 [=Synodica I].

Troisième Conférence Panorthodoxe Préconciliaire, Communiqué[Chambésy, 6 novembre 1986], „Episkepsis” 17 (1986) nr 366, s. 21-23.

Troisième Conférence Panorthodoxe Préconciliaire, Contribution de l'Église orthodoxe à la réalisation de la paix, de la justice, de la liberté, de la fraternité et de l'amour entre les peuples, et à la suppression des discriminations raciales et autres, „Episkepsis” 17 (1986) nr 369, s. 18-26; tłum. polskie: NSO, s. 418-429.

Troisième Conférence Panorthodoxe Préconciliaire, Église orthodoxe et mouvement oecuménique, „Episkepsis” 17 (1986) nr 369, s. 14-17; tłum. polskie: NSO, s. 413-417. 
Troisième Conférence Panorthodoxe Préconciliaire, Importance du jeûne et son observance aujourd'hui, „Episkepsis” 17 (1986) nr 369, s. 6-8; tłum. polskie: NSO, s. 402-405.

Troisième Conférence Panorthodoxe Préconciliaire, Règlement des Conférences Panorthodoxes Préconciliaires, „Episkepsis” 17 (1986) nr 369, s. 2-5; tłum. polskie: T NSO, s. 440-447.

Troisième Conférence Panorthodoxe Préconciliaire, Relations de l'Église orthodoxe avec l'ensemble du monde chrétien, „Episkepsis” 17 (1986) nr 369, s. 9-13; tłum. polskie: NSO, s. 406-412.

Verfahrens- und Arbeitsordung der I. Panorthodoxen Konferenz von Rhodos (25.09.1961), [w:] A. Kallis, Auf dem Weg zu einem Heiligen und Großen Konzil, Münster 2013, s. 246-250.

\section{Literatura}

Allocution du Patriarche Cyrille de Moscou à la synaxe des primats des Églises orthodoxes [22 janvier 2016], https://mospat.ru/fr/2016/01/22/news127085/ (28.01.2016).

Athenes, debut des travaux de la commission spéciale pour la préparation du concile panorthodoxe, https://mospat.ru/fr/2015/12/16/news126119/ (21.12.2015).

Clément O., Tous, préparons ensemble le Concile, [w:] Synodica I, s. 105-125.

Evdokimov P., Clément O., Vers le Concile. Appel à l'Église, „Contacts” 23 (1971) nr 73-74, s. 193-210.

Fin de la réunion de la commission interorthodoxe spéciale pour la préparation des documents ddu concile panorthodoxe [2.04.2015], https://mospat.ru/ fr/2015/04/03/news117382/ (21.12.2015).

Hilarion (Alfeyev), Le saint et grand concile de l'Église orthodoxe, „Irénikon” 84 (2011) nr 2-3, s. 203-244.

Ionita V., Auf dem Weg zum Heiligen und Großen Konzil der Orthodoxen Kirche, „Una Sancta” 70 (2015) nr 2, s. 82-92.

Ionita V., Towards the Holy and Great Synod of the Orthodox Church. The Decisions of the Pan-Orthodox Meetings since 1923 until 2009, Basel 2014.

Jerzy (Pańkowski), Aktualny stan przygotowań do Soboru Panprawosławnego, „Elpis” 12 (2010) nr 21-22, s. 163-175.

Kałużny T., Nowy sobór ogólnoprawosławny. Natura, historia przygotowań, tematyka, Kraków 2008 [=NSO].

Kałużny T., Problem eklezjalnej jedności prawosławia $w$ dzisiejszej Europie, „Studia Oecumenica” 8 (2008), s. 77-93. 
Константинополь признал митрополита Ростислава предстоятелем Церкви Чешских земль, http://regions.ru/news /2569691/ (15.01.2016).

La deuxième session de la commission inter-orthodoxe pour la préparation du saint et grand concile s'est achevée, http://www.orthodoxie.com/?s=\%C3\%A9tropolit e+J\%C3\%A9r\%C3\%A9mie+de+Suisse\& $\mathrm{x}=1189 \& \mathrm{y}=227$ (21.12.2015).

La formation du peuple chrétien pour le futur Grand Concile de l'Église orthodoxe, „Episkepsis” 2 (1971) nr 23, s. 5-7.

Lossky N., Przygotowanie do Soboru panprawosławnego, „Novum 12 (1978) nr 1, s. 12-20.

La session de la commission spéciale inter-orthodoxe pour la préparation du concile panorthodoxe s'est achevée, http://orthodoxie.com/la-session-de-la-commissionspeciale-inter-orthodoxe-pour-la-preparation-du-concile-panorthodoxe-sestachevee/ (21.12.2015).

Oeldemann J., Kommt das Panorthodoxe Konzil? Alte Konflikte und neue Konstellationen in der Orthodoxen Kirche, „Herder Korrespondenz” (2010) nr 11, s. 553-557.

Popovitch J., Lettera sul Concilio [1971], „Oriente Cristiano” 17 (1977) nr 4, s. 103-113.

Przygotowania do Soboru Wszechprawosławnego: http://ekai.pl/wydarzenia/ ekumeniczne/x95268/przygotowania-do-soboru-wszechprawosławnego/ (8.01.2016).

\section{The Orthodox Church on Her Way toward the Holy and Great Council}

\section{SUMMARY}

The article aims at presenting in a comprehensive way the history of the Orthodox Church preparing for her new Council. The subject is treated in three parts. First, the author is discussing the early preparations for the Pan-Orthodox Council, ie, the individual initiatives of some local Orthodox Churches aiming at summoning the Council. In the second part, the author is presenting the immediate preparation for the Council started by the Pan-Orthodox Conference on Rhodes in 1961. The initiatives taken up at this stage have a character of an official organized process of preparations for the Council encompassing the whole Orthodox world. In the last part, the author is focusing on the basic difficulties that have appeared on the way of the preparations for 
the Council. In principle, they centre around the following three issues: doubts concerning the need and possibility for summoning the Council, reservations about the process of preparations for the Council, problems concerning some inter-Orthodox relations. As a conclusion, the author asserts that the preparations for the Holy and Great Council of the Orthodox Church have had a long and rich history. Although so far it has not been possible to put into effect the idea of the Pan-Orthodox Council, the perspective of summoning such a council seems to be closer and closer.

KEYWORDS: Orthodoxy, Orthodox Church, Pan-Orthodox Council, Holy and Great Council of the Orthodox Church

SŁOWA KLUCZOWE: prawosławie, Kościół prawosławny, Sobór Wszechprawosławny, Święty i Wielki Sobór Kościoła prawosławnego 